The "Bubbling" Method and Vapour Pressures.

In the course of an endeavour to determine the osmotic pressure of a solution by measuring the relative lowering of its vapour pressure, we have been led to abandon Oswald and Walker's bubbling method on account of its inherent inaccuracy.

As the disabilities of this method seem to have been overlooked, we think that this note may be of use to other workers in the same field.

Oswald and Walker, it will be remembered, bubbled dry air through the solution, then through the water, and absorbed the moisture by means of sulphuric acid. The loss of weight of the water measures the relative lowering of the vapour pressure of the solution, and the gain in weight of the sulphuric acid represents the vapour pressure of the pure solvent, water.

Assuming the air to be at the same temperature throughout, it can easily be seen that the space occupied by a bubble of air, when leaving the solution, will be less than that which the same bubble will occupy when leaving the water, that is, the bubble expands while travelling up the water column, and will have taken up more water vapour than it should. The expansion of the bubble (and consequently the amount of vapour necessary to saturate the space occupied by it) is proportional to the difference in pressure at the top and bottom of the water column. If the total depth of the latter be, say, 6 inches, and the barometer stand at 30 feet of water, then an error of I part in 60 is induced.

This can conveniently be verified by passing air through two or more Winkler's tubes filled with water; it will always be found that the exit tube has lost weight. Owing to the form of the equation connecting osmotic and vapour pressures, the effect of the above error is magnified.

Foxcombe, near Oxford. BERKELEY.

\section{Luminosity and Colour.}

IN conjunction with my other methods of testing colour vision, I have been using Rayleigh's apparatus for matching yellow with a mixture of spectral red and green. I find that the proportions of red and green depend upon the luminosity of the match (both the mixed colour and the simple one being of similar luminosity); for instance, I require two and a half times as much green in the mixed colour when the match is bright compared with a match at a lower luminosity. Some persons make a match which is nearly the same at several luminosities, others require more and more green as the luminosity is diminished, and others when the luminosity is diminished cannot make a match at all. So three normal sighted persons may make a similar match at one luminosity, and at another one may appear to be an anomalous trichromatic and the other colour blind. I find that a colour blind person (a dichromic with considerable shortening of the red end of the spectrum) may make a match like a normal sighted one.

St. John's College, Cambridge.

\section{MEETING OF THE BRITISH ASSOCIATION} IN SOUTH AFRICA.

THE arrangements for the forthcoming meeting of the British Association in South Africa have now been completed, and Mr. Silva White, the assistant secretary of the association, sailed for Cape Town in the Walmer Castle on Saturday last, July I. The number of members who will proceed to South Africa to attend the meeting is 385 , and of these no less than 276 members have intimated their intention to visit the Victoria Falls at the conclusion of the ordinary work of the association. The official party, consisting of leading representatives of science and guests of the association, with the general and sectional officers for this meeting and the president, numbers 140 in all, and will sail by the Saxon on July 29. Most of the other members will proceed to the meeting by the Durham Castle and the Kildonan Castle, both of which sail on July 22 .

$$
\text { No. I862, voL. 72] }
$$

In a previous article (May 18, p. 59) the local arrangements for the meeting were described. There will be receptions and social functions, excursions, \&c., at Cape Town, Durban, Pietermaritzburg, Johannesburg, Kimberley, and Bulawayo. The central organising committee for South Africa (chairman, Sir David Gill, K.C.B., F.R.S., hon. secretary, Dr. Gilchrist) has carried out the coordinating work of the programme. The lists of local committees and subcommittees contain nearly one thousand names, from which it may be concluded that much interest is taken in the meeting.

As already mentioned, lectures of a popular character will be delivered at the chief towns visited. These lectures have now been definitely arranged as follows :-

Cape Town: W. J. Burchell's discoveries in South Africa, Prof. Poulton; some surface actions of fluids, Mr. C. V. Boys. Durban: Mountains: the highest Himalaya, Mr. D. Freshfield. Pietermaritzburg: Sleeping-sickness, Colonel D. Bruce. Johannesburg: Distribution of power, Prof. Ayrton; steel as an igneous rock, Prof. Arnold. Pretoria: Fly-borne diseases, malaria, sleeping-sickness, \&c., Mr. A. E. Shipley. Bloemfontein: The Milky Way and the clouds of Magellan, Mr. A. R. Hinks. Kimberley: Diamonds, Sir William Crookes; bearing of engineering on mining, Prof. Porter. Bulawayo: Zimbabwe, Mr. Randall-MacIver.

The president's address to the association will be delivered at Cape Town on August. 15, and at Johannesburg on August 3o. Mr. G. W. Lamplugh's report on the geology of the Victoria Falls will take the form of an afternoon address to Section $\mathrm{C}$ at Johannesburg.

Subjoined is a draft programme of the work of the sections :-

Section A (Mathematics and Physics).-Cape Town: President's address; progress of the arc of meridian and geodetic survey of South Africa, Sir D. Gill; to what extent can the ether affect the motion of matter? Prof. J. Larmor; observations of atmospheric electricity in South Africa, Prof. Beattie and Mr. Lyle; leak of electricity from certain heated substances, Prof. Beattie; the foundations of the kinetic theory of gases, Mr. Burbury; application of the kinetic theory of nebulæ, Mr. J. H. Jeans: radiation at low temperatures, Dr. J. T. Bottomley. There will also probably be communications from Mr. Hough on tides, and from Dr. Roberts on the Algol variables. Johannesburg: On the teaching of elementary mechanics (jointly with Section L if possible), Prof. J. Perry; on flight, Prof. G. H. Bryan; (I) electrical conductivity in relation to chemical action; (2) magnetic survey of South Africa, Prof. Beattie; report of the seismological committee, Prof. J. Milne; a form of dry Daniell cell, Mr. J. Brown; the strength of winding ropes in mines, Prof. Perry; the experimental foundations of the theory of heat conduction, Dr. C. H. Lees. There will probably be a communication from Mr. Sutton on the meteorology of South Africa.

Section B (Chemistry).--Detailed information regarding papers offered by members in South Africa has not yet been received, but the following provisional arrangement has been made:-Cape Town: Recent advances in agricultural science, A. D. Hall; vegetable assimilation, Dr. Horace T. Brown; enzyme action, Dr. E. F. Armstrong. These communications are intended to serve as a basis of discussion of agricultural chemical problems. Johannesburg: President's address; reports on various aspects of the metallurgy of gold by local experts. Communications by Dr. H. Marshall on the experimental basis of the dissociation hypothesis, and by $\mathrm{H}$. Ingle on the soils of the Transvaal, have been provisionally accepted.

Section C (Geology).-Cape Town: Opening remarks by the president; the continent of Africa in relation to the physical history of the earth. Prof. W.. J. Sollas; the classification of the Karroo beds of South Africa, Prof.. R. Broom; report of the committee on the fauna and flora 
of the English Trias, J. Lomas; extraordinary daily fluctuations in a Karroo well, Prof. A. Young; and other papers on the Karroo or Trias. Joint meeting with Section $E$ (Geography).-The physical geography of Cape Colony, H. C. Schunke-Holloway; Glacial periods in South Africa, A. W. Rogers; changes of climate, as shown by movements of the snow line and upper tree line since Tertiary times, Prof. A. Penck; physiographical subject, Prof. W. M. Davis; Baviaan's Kloof, a contribution to the theory of mountain folds, E. H. L. Schwarz; the Stormberg formation in the Cape Colony, A. L. Du Toit; on the geology of South Victoria Land, H. T. Ferrar. Johannesburg: President's address; magnetic segregation of sulphide ores, Dr. A. P. Coleman; marginal phenomena of granite domes, Prof. G. A. J. Cole; relation of the igneous rocks to the crystalline schists, F. P. Mennell; the indicators of the goldfield of Ballarat, Prof. J. W. Gregory; petrographical subject, Prof. R. B. Young; the diamond pipes and fissures of South Africa, H. S. Harger; recent work of the Transvaal Geological Survey, H. Kynaston; the Victoria Falls, G. W. Lamplugh; the great laccolitic intrusions of the Bushveld, Dr. G. A. F. Molengraaff; evidences in the Transvaal of Glacial conditions in permo-Carboniferous times, E. T. Mellor; geological notes on the excursion to Pretoria, A. L. Hall; the great West Rand upthrust, Dr. J. T. Carrick; notes on a sedimentary formation older than the Witwatersrand beds, E. Jorissen; interesting outlines of the Witwatersrand formation, Dr. J. T. Carrick.

Section D (Zoology).-Cape Town: President's address; the Triassic reptiles of South Africa, with remarks on the origin of mammals, Dr. Broom; a comparison of the Permian reptiles of Russia with those of South Africa, Prof. Amalitzky; South African scorpions, Dr. Purcell; recent work on gametogenesis and its bearing on theories of heredity, L. Doncaster; the migration of birds in the southern hemisphere, W. L. Sclater; the ostrich, A. H. Evans. Johannesburg: Pearl oysters and pearls, Prof. Herdman; recent discoveries in the South African deep sea, Dr. Gilchrist ; cephalodiscus, Dr. Harmer; the growing-point in vertebrates, Prof. Cleland; South African ticks, Drs. Cooper-Foster and Nuttall.

Section E (Geography).-Cape Town: President's address; afforestation of South Africa; the unveiling of the coasts of Africa (lantern views of old maps), H. Yule Oldham; the Ordnance Survey of the United Kingdom, Colonel Johnston; a comparison of the periodicity of the meteorological conditions of London and Cape Town, Dr. H. R. Mill; Gough Island, Rudmose Brown; terrestrial globes as a necessary adjunct to the teaching of geography, Captain Creak; : excursions as a means of teaching geography (lantern), J. Lomas. Johannesburg: The evolution of Africa, Dr. J. Scott Keltie; a new rainfall map of Africa, A. J. Herbertson and P. C. Waite; boundaries and areas in Africa, J. Bolton; the physical geography of the Transvaal, Tudor Trevor; notes on the geography of Africa south of the Limpopo, F. S. Watermeyer; the game preserves of the Transvaal, Major Stevenson Hamilton, D.S.O.; the Sikhim Himalayas and Tibet, Douglas W. Freshfield; Asiatic subject, Prof. Cordier.

Section G (Engineering).-Cape Town: Metcalfe on Zambezi Bridge and Rhodesian railways; ocean turbine boats, Prof. Byles; roller bearings, wire ropes in mines, and probably automobiles. Johannesburg: President's address (irrigation); strength of winding ropes in mines, Prof. Perry.

Section H (Anthropology).-Cape Toren: President's address; the totemism of the Bantu, E. S. Hartland; the musical instruments of the natives of South Africa, $\mathrm{Hy}$. Balfour; American Negroes, Miss Pullen-Burry; artificial deformation in Africa, Dr. von Luschan. Johannesburg: arts and crafts among the natives of South Africa, Dr. Schoenland; stone implements in South Africa, Mr. Johnstone; bushman paintings with reproductions, Dr. Squire; the affinities of the Hottentots, Dr. von Luschan; the Modjadje, Rev. Reuter; the Bawenda, Rev. Gottschling; report on Zimbabwe, Mr. Maclver; the Basuto, H. E. Mabille.

Section I (Physiology).-Cape Town: Discussion on the effect of climate on health, opened by Sir T. Lauder Brunton (Dr. David Ferrier, Prof. McKendrick, Dr. NO. I 862 , vOL. 72$]$
Gregory, Dr. Jasper Anderson, Prof. Bohr, and Dr. J. A. Mitchell will take part); so-called scurvy of South Africa, Dr. Gregory; on plague, Dr. J. A. Mitchells leprosy in Cape Colony, Dr. A. S. Black; South African drugs, Dr. Moberley; discussion on horse-sickness and allied diseases, opened by Dr. Edington (Dr. Hutcheon, Mr. du Plessis, Dr. Wm. Robertson, Colonel Bruce, and Prof. Sims Woodhead will take part); stock diseases in South Africa, Dr. Hutcheon; ticks as a means of conveying disease in South Africa, Mr. Lounsbury. Johannesburg: President's address; horse-sickness, Dr. Theiler; rinderpest, Dr. G. Turner; a discussion on lung diseases in connection with mining (Dr. Sims Woodhead) is under consideration; nervous diseases, Prof. Ferrier; the life-history of coloured labourers in the Transvaal, Dr. D. Macaulay and Dr. Louis Irvine; dysentery, Colonel Cecil Birt.

Section $\mathrm{K}$ (Botany).-Cape Town: The present position of our knowledge of seaweeds, Prof. R. W. Phillips; the fossil floras of South Africa, A. C. Seward; educational methods in the teaching of botany, Harold Wager; notes on irrigation farming on the Orange River, F. B. Parkinson. Johannesburg: President's address; photography as an aid to œecological research, Prof. F. E. Weiss; the problems of heredity, R. P. Gregory. It is expected that Prof. Engler, Prof. Pearson, and others will contribute papers.

Section L (Educational Science).-Cape Tozn: President's address; the teaching of science, Prof. H. E. Armstrong; the teaching of science in South Africa, Dr. Hahn; rural education, appropriate to colonial life in South Africa, and agriculture, A. D. Hall; the higher education of women in South Africa, Miss Clark; disabilities of South African school boys, W. A. Way; Cape education, its difficulties and development, Rev. W. E. C. Clarke. Johannesburg: Changes in the Dutch language since its introduction into South Africa, Dr. Brill; education on the veldt, Mr. Corbett; prospects of secondary schools in the Transvaal, $\mathrm{Mr}$. Hope; teaching of agriculture, F. B. Smith; native education. Hobart Houghton; progress of education in the Transvaal, H. Warre Cornish; education in Rhodesia, G. Duthie; a school of forestry, T. R. Simms; the teaching of architecture, R. G. Kirkby; education in the Orange River Colony, Hugh Gunn; manual instruction in the Transvaal, $T$. Lowden; recent improvements in the training of infants, with special reference to South Africa, Miss Welldon; discussion with Section $A$, the teaching of elementary mathematics.

\section{THE PRINCIPLES OF GEOLOGY.1}

THE principles are, notwithstanding the origin of the word, the last things you attain to in the course of scientific investigation; but they are what you first explain to another who is commencing his study. You may make a further selection of such parts as are for any reason the easiest or most suitable for him to begin with, and call them the elements. Lyell's classic work has pretty well fixed what shall be the conventional meaning of "The Principles of Geology." They are the laws or explanations which we arrive at in respect of the phenomena exhibited in the earth's crust from direct observation of those phenomena themselves or of the recent operations of nature which we see producing analogous results. Their value depends upon the opportunities afforded of obtaining evidence and upon the personal faculty of eliminating sources of error.

In the case of geology, the subject is so vast that its different branches are growing further and further apart, until they seem to have an intergrowth with the branches from other subjects the original stem of which was far removed from their own.

From the observation of rock masses inferences have been drawn as to the conditions which prevailed in past times, and theories have been propounded as

1 "Structural and Field Geology." By Dr. Jas. Geikie. Pp. $\mathbf{x x}+435$. (Edinburgh: Oliver and Boyd; London: Gurney and Jackson, 1905.)
Price I2s. 6d. net. 